\title{
PENGARUH BIOCHAR SEKAM PADI DAN KOMPOS TERHADAP C ORGANIK, N TOTAL, C/N TANAH, SERAPAN N, DAN PERTUMBUHAN TANAMAN JAGUNG DI ULTISOL
}

The Effect of Rice Husk Biochar and Compost on Soil Organic Carbon,
Total N, and C/N of Soil, N uptake, and Growth of Maize in an Ultisol

\author{
Geraldine Abel $^{* 1}$, Retno Suntari ${ }^{1}$, Ania Citraresmini ${ }^{2}$ \\ ${ }^{1}$ Jurusan Tanah, Fakultas Pertanian, Universitas Brawijaya, Jl. Veteran No. 1, Malang 65145 \\ 2 Pusat Aplikasi Isotop dan Radiasi, BATAN Jl. Lebak Bulus Raya No. 49, Jakarta 12440 \\ *Penulis korespondensi: geraldineabell@gmail.com
}

\begin{abstract}
The maize crop is an important commodity other than rice in Indonesia. Maize production reached 30 million tons in 2018. Efforts that can be made to increase maize production on Ultisols in Indonesia is by the application of biochar rice husk and compost. Biochar that has a high affinity for nutrients does not experience decay in the soil for decades, while compost can improve soil chemical properties by increasing nutrient content. The purpose of this study was to analyze the effect of the application of a combination of rice husk biochar and compost on soil chemical properties, $\mathrm{N}$ uptake, and growth of maize on an Ultisol. This study was conducted with six treatments. The results showed that the application of a combination of rice husk biochar and compost had an effect on increasing the C-organic and $\mathrm{N}$ total in soil, but it did not affect the $\mathrm{C} / \mathrm{N}$ of the incubated soil. Application of a combination of $8 \mathrm{t}$ rice husk biochar ha- $\mathrm{a}^{-1}$ and 30 compost ha- $^{-1}$ significantly improved plant height, dry weight, and $\mathrm{N}$ uptake of maize plants.
\end{abstract}

Keywords : compost, maize, rice husk biochar, soil chemical properties, Ultisol

\section{Pendahuluan}

Tanaman jagung merupakan komoditas penting selain padi di Indonesia. Jagung dapat digunakan sebagai pakan ternak, bahan pangan, dan tongkolnya sebagai biochar dan bioetanol. Banyaknya manfaat dari tanaman jagung memacu petani untuk menanam tanaman jagung, produksi jagung di Indonesia pada tahun 2018 mencapai 30 juta ton (Badan Ketahanan Pangan RI (2018)). Kebutuhan jagung di Indonesia diperkirakan sekitar 15,5 juta ton. Upaya yang dapat dilakukan untuk meningkatkan produksi jagung adalah dengan menanam jagung di lahan Ultisol.

Ultisol adalah tanah yang tersebar luas di Indonesia mencapai 45.794.000 ha atau sekitar $25 \%$ dari total luas daratan di Indonesia dan memiliki potensi yang besar untuk ditanami tanaman pangan (Syahputra et al., 2015). Ultisol termasuk tanah yang kurang subur dengan $\mathrm{pH}$, unsur hara, dan daya serap air yang rendah. Kandungan liat yang tinggi juga menyebabkan Ultisol menghambat akar tanaman dalam penyerapan hara dan oksigen, serta kandungan Al dan Mn yang berpotensi meracuni tanaman budidaya (Andalusia et al., 2016). Ditambahkan bahwa Ultisol memiliki kapasitas tukar kation (KTK), kejenuhan basa (KB), dan kandungan C organik yang rendah, serta tingginya curah hujan di Indonesia dapat mencuci basa basa di dalam Ultisol sehingga $\mathrm{KB}$ rendah dan basa yang tersisa di dalam tanah bereaksi masam (Mulyani et al., 2010).

Aplikasi biochar sekam padi mampu meningkatkan kandungan $\mathrm{C}$ organik dan $\mathrm{N}$ total pada Ultisol karena karena karbon di dalam biochar bersifat stabil dan tidak mudah terdekomposisi oleh mikroorganisme tanah, 


\section{Jurnal Tanah dan Sumberdaya Lahan Vol 8 No 2: 451-460, 2021 e-ISSN:2549-9793, doi: 10.21776/ub.jts1.2021.008.2.16}

selain itu permukaan oksida pada biochar dapat menjerap $\mathrm{NH}_{4}^{+}$dan $\mathrm{NO}^{3-}$ sehingga mencegah terjadinya kehilangan $\mathrm{N}$ di dalam tanah (Putri $e t$ al., 2017). Ditambahkan bahwa permukaan hidrofobik biochar dapat menjerap molekul organik seperti ion $\mathrm{Al}^{3+}$ dan $\mathrm{Fe}^{3+}$ serta meningkatkan konsentrasi dari logam alkali oksida seperti $\mathrm{Ca}^{2+}, \mathrm{Mg}^{2+}$, dan $\mathrm{K}^{+}$(De Luca et al., 2009). Di lain pihak, pupuk kompos dapat meningkatkan kandungan $\mathrm{C}$ organik karena kompos melepaskan asam asam organik setelah proses dekomposisi oleh mikroorganisme tanah dan melalui proses dekomposisi kandungan $\mathrm{N}$ total di dalam tanah akan meningkat (Firnia, 2009). Oleh karena itu, penelitian dengan aplikasi biochar sekam padi yang dikombinasikan dengan kompos bertujuan untuk mengetahui pengaruh nyata terhadap sifat kimia tanah, serapan $\mathrm{N}$, dan pertumbuhan tanaman jagung pada Ultisol.

\section{Bahan dan Metode}

\section{Tempat dan waktu penelitian}

Penelitian dilaksanakan di Pusat Aplikasi Isotop dan Radiasi Badan Tenaga Nuklir Nasional (PAIR BATAN), Pasar Jumat, Jakarta Selatan, Provinsi DKI Jakarta. Penanaman dilakukan di rumah kaca dan analisis tanah dan tanaman dilakukan di laboratorium Kelompok Pemupukan dan Nutrisi Tanaman PAIR BATAN. Waktu pelaksanaan penelitian dimulai pada akhir bulan Februari sampai Maret 2020 lalu dilanjutkan pada bulan Agustus sampai Desember 2020.

\section{Rancangan percobaan}

Penelitian ini menggunakan metode Rancangan Acak Kelompok (RAK). Penelitian dilakukan 2 set yaitu tanah inkubasi (tidak ditanami jagung) dan tanah yang ditanami jagung. Dosis aplikasi biochar (B) dan kompos (K) berdasarkan rekomendasi Verdiana et al. (2016) dan Pane et al. (2014) untuk perbandingan 1:1 adalah $4 \mathrm{t} \mathrm{ha-}$ ${ }^{1}$ : $30 \mathrm{t} \mathrm{ha}^{-1}$. Pupuk NPK dengan dosis $300 \mathrm{~kg}$ $\mathrm{ha}^{-1}$ diaplikasikan pada tiap perlakuan. Dosis dari tiap perlakuan adalah sebagai berikut: N0 (kontrol), N1 (1B), N2 (1K), N3 (1B+1K), N4 $(2 \mathrm{~B}+1 \mathrm{~K})$, dan N5 $(1 \mathrm{~B}+2 \mathrm{~K})$. Setiap perlakuan diulang sebanyak 4 kali sehingga didapatkan 48 plot percobaan.

\section{Pelaksanaan penelitian}

Persiapan biji jagung, media tanam, biochar dan kompos

Biji jagung menggunakan varietas Pioneer 21 yang sudah direndam di dalam larutan ATCC yang berisi bakteri penghasil eksopolisakarida. Tanah yang sudah diayak, kemudian dihomogenkan dan dimasukkan ke dalam pot 1 $\mathrm{kg}$ (inkubasi) dan $10 \mathrm{~kg}$ (ditanami jagung). Biochar yang digunakan untuk penelitian ini berasal dari sekam padi. Biochar dibuat dengan metode pirolisis dengan suhu $200^{\circ} \mathrm{C}$, selama 2 jam. Sementara kompos yang digunakan merupakan kompos dalam bentuk kemasan dan sebelum digunakan kompos dikering anginkan terlebih dahulu.

Perawatan tanaman (pemupukkan, penyiangan gulma dan penyiraman)

Pemupukan NPK dilakukan 2 kali dalam 1 musim tanam yaitu pada 0 dan 30 hari setelah tanam (HST). Penyiangan gulma dilakukan secara manual untuk menghindari adanya persaingan unsur hara antara gulma dengan tanaman jagung. Penyiraman tanaman dilakukan sesuai kadar air kapasitas lapang

Pengamatan tanaman jagung

Pengamatan tanaman terdiri dari 2, yaitu secara destruktif dan non destruktif.

a. Pengamatan non destruktif

Tinggi dan jumlah daun yang diukur dan dihitung pada 1, 3, dan 5 MST.

b. Pengamatan destruktif

Pengamatan ini berupa berat kering tanaman jagung yang ditimbang setelah panen (7 MST), kemudian dikeringkan di dalam oven selama $2 \times 24$ jam dengan suhu $60^{\circ} \mathrm{C}$. Setelah itu digiling halus hingga lolos ayakan 20 mesh sebelum dianalisis.

\section{Analisis tanah dan tanaman}

Analisis kimia tanah inkubasi dilakukan pada 4 MSI (masa setelah inkubasi) dan 7 MSI sementara pada tanah ditanami jagung dan analisis tanaman dilakukan pada 7 MST. Tanah yang lolos ayakan $0,5 \mathrm{~mm}$ ditimbang untuk dianalisis $\mathrm{C}$ organik dan $\mathrm{N}$ total tanah dan tanaman dengan metode $W$ alkley and Black dan Kjeldabl. 


\section{Jurnal Tanah dan Sumberdaya Lahan Vol 8 No 2: 451-460, 2021 e-ISSN:2549-9793, doi: 10.21776/ub.jts1.2021.008.2.16}

\section{Analisis data}

Analisis data untuk mengetahui pengaruh perlakuan terhadap parameter diamati menggunakan ANOVA (analysis of variance). $\mathrm{Uji}$ lanjut dilakukan dengan menggunakan Duncan's Multiple Range Test (DMRT 5\%) dengan software Genstat. Uji korelasi dilakukan dengan menggunakan uji korelasi Pearson untuk mengetahui hubungan linear dari parameter pengamatan. Apabila berpengaruh nyata dengan $\mathrm{r}$ tabel taraf 5\% dilanjutkan dengan uji regresi.

\section{Hasil dan Pembahasan}

\section{Hasil analisis dasar tanah}

Hasil analisis dasar tanah tidak sejalan dengan pernyataan Ermadani dan Muzar (2011) bahwa Ultisol memiliki $\mathrm{pH}<4,5$, kandungan liat $>$ $70 \%$, dan kandungan hara makro yang rendah, sementara pada Ultisol yang digunakan untuk penelitian memiliki $\mathrm{pH}$ sebesar 6,3 dan kandungan $\mathrm{K}$, Ca dan Mg secara berturut-turut sebesar $0,43,8,95$, dan 4,87 $\mathrm{cmol} \mathrm{kg}^{-1}$ dan tidak termasuk dalam kategori rendah. Ditambahkan oleh Wahyuningtyas (2011) bahwa Ultisol memiliki $\mathrm{KB}<35$, sementara pada Ultisol yang digunakan untuk penelitian memiliki nilai $\mathrm{KB}$ sebesar 90\%. Hasil analisis $\mathrm{N}$ total Ultisol sejalan dengan penelitian Syahputra et al. (2015) bahwa kandungan $\mathrm{N}$ total tanah tergolong sangat rendah. Hasil analisis dasar tanah disajikan pada Tabel 1.

Perbedaan kriteria dapat terjadi karena Ultisol yang digunakan sering digunakan untuk penelitian lainnya dan terjadi pengaplikasian pupuk yang intensif. Akibatnya, $\mathrm{pH}$ dan beberapa kandungan hara di dalam tanah berbeda dengan kriteria Ultisol. Hal ini sejalan dengan pernyataan Siregar dan Supriadi (2017) bahwa aplikasi pupuk organik mampu meningkatkan $\mathrm{pH}$ tanah karena bahan organik pada pupuk akan melepaskan senyawa-senyawa organik, baik berupa asam asam organik maupun kation-kation basa melalui proses dekomposisi.

Tabel 1. Hasil analisis dasar tanah.

\begin{tabular}{|c|c|c|c|}
\hline No. & Parameter tanah & Hasil analisis & Kriteria* \\
\hline 1. & $\mathrm{pH}$ & 6,3 & Agak masam \\
\hline 2. & C- organik $(\%)^{*}$ & 1,48 & Rendah \\
\hline 3. & $\mathrm{~N}(\%)$ & 0,13 & Rendah \\
\hline 4. & $\mathrm{C} / \mathrm{N}$ & 11 & Sedang \\
\hline 5. & P- tersedia $(\mathrm{ppm})$ & 34,81 & Sangat tinggi \\
\hline 6. & $\mathrm{~K}\left(\mathrm{cmol} \mathrm{kg}^{-1}\right)$ & 0,43 & Sedang \\
\hline 7. & $\mathrm{Ca}\left(\mathrm{cmol} \mathrm{kg}^{-1}\right)$ & 8,95 & Sedang \\
\hline 8. & $\mathrm{Mg}\left(\mathrm{cmol} \mathrm{kg}^{-1}\right)$ & 4,87 & Tinggi \\
\hline 9. & Kapasitas tukar kation $\left(\mathrm{cmol} \mathrm{kg}^{-1}\right)$ & 16,20 & Sedang \\
\hline 10. & Kejenuhan basa (\%) & 90 & Sangat Tinggi \\
\hline 11. & Tekstur: & & \multirow{4}{*}{ Liat } \\
\hline \multirow{3}{*}{11} & - Pasir (\%) & 9 & \\
\hline & - $\quad$ Debu $(\%)$ & 33 & \\
\hline & - $\quad$ Liat $(\%)$ & 58 & \\
\hline
\end{tabular}

Keterangan: * Kriteria menurut Balai Penelitian Tanah (2009).

\section{Pengaruh biochar dan kompos terhadap sifat kimia tanah}

Biochar dan kompos merupakan bahan organik yang diharapkan dapat memperbaiki sifat kimia tanah. Peningkatan kesuburan tanah akan meningkatkan unsur hara yang cukup di dalam tanah sehingga dapat menunjang pertumbuhan tanaman. Sifat kimia tanah yang diamati untuk mengetahui pengaruh dari aplikasi kombinasi biochar sekam padi dan kompos antara lain $\mathrm{C}$ organik, $\mathrm{N}$ total tanah, dan rasio $\mathrm{C} / \mathrm{N}$.

Corganike

C organik berperan penting dalam memperbaiki sifat fisik, kimia, dan biologi tanah. C organik di 


\section{Jurnal Tanah dan Sumberdaya Lahan Vol 8 No 2: 451-460, 2021 e-ISSN:2549-9793, doi: 10.21776/ub.jts1.2021.008.2.16}

dalam tanah juga berperan sebagai substrat dan habitat bagi mikroorganisme tanah. Pengaruh aplikasi kombinasi biochar sekam padi dengan kompos terhadap C organik tanah disajikan pada Tabel 2. Hasil analisis ragam menunjukkan pengaruh nyata aplikasi kombinasi biochar sekam padi dan kompos terhadap parameter $\mathrm{C}$ organik tanah inkubasi dan tanah ditanami jagung. Perlakuan N4 $(2 \mathrm{~B}+1 \mathrm{~K})$ memberikan $\%$ $\mathrm{C}$ organik tertinggi tanah inkubasi dan tanah yang ditanami jagung pada 4 MSI, 7MSI, dan 7 MST secara berturut turut sebesar 2,64, 3,30, dan $2,76 \%$.

Perlakuan kontrol tanah inkubasi dan tanah ditanami jagung menghasilkan nilai kadar C organik terendah. Hasil uji lanjut DMRT taraf 5\% pada tanah inkubasi menunjukan bahwa perlakuan $\mathrm{N} 4(2 \mathrm{~B}+1 \mathrm{~K})$ tidak berbeda nyata dengan perlakuan N2, N3, dan N5 $(1 \mathrm{~K}, 1 \mathrm{~B}+$ $1 \mathrm{~K}$, dan $1 \mathrm{~B}+2 \mathrm{~K})$, namun berbeda nyata dengan perlakuan N1 (biochar) pada 4 dan 7 MSI. Selain itu, hasil uji lanjut DMRT taraf 5\% pada tanah ditanami jagung menunjukkan bahwa perlakuan $\mathrm{N} 4(2 \mathrm{~B}+1 \mathrm{~K})$ tidak berbeda nyata dengan perlakuan $\mathrm{N} 3$ dan $\mathrm{N} 5(1 \mathrm{~B}+1 \mathrm{~K}$ dan $1 \mathrm{~B}+2 \mathrm{~K})$, namun berbeda nyata dengan perlakuan N1 dan N2 (1B dan 1K). Hal ini sejalan dengan pernyataan Gani (2009) aplikasi biochar ke dalam tanah berpotensi meningkatkan kandungan $\mathrm{C}$ organik dan unsur hara di dalam tanah. Serta salah satu keuntungan dari menggunakan biochar adalah karena sifatnya yang stabil dan tersimpan dalam waktu yang lama di dalam tanah. Menurut Widodo dan Kusuma (2018) aplikasi kompos juga dapat meningkatkan kandungan $\mathrm{C}$ di dalam tanah, karena adanya pelepasan unsur $\mathrm{C}$ di dalam kompos. Di lain pihak kompos mengandung senyawa- senyawa organik seperti asam fulvat dan asam humat, menurut Firda et al. (2016) asam humat memiliki kandungan unsur $\mathrm{C}$ sebesar $40-80 \%$.

Tabel 2. Pengaruh aplikasi biochar dan kompos terhadap C organik tanah.

\begin{tabular}{cccccccc}
\hline \multirow{2}{*}{ Kode } & Perlakuan & \multicolumn{5}{c}{ C organik tanah (\%) } \\
\cline { 3 - 7 } & & \multicolumn{4}{c}{ Tanah Inkubasi } & \multicolumn{3}{c}{ Tanah ditanami Jagung } \\
\cline { 3 - 7 } & & 4 MSI & $*$ & 7 MSI & $*$ & 7 MST & * \\
\hline N0 & Kontrol & $1,80 \mathrm{a}$ & Rendah & $1,82 \mathrm{a}$ & Rendah & $1,65 \mathrm{a}$ & Rendah \\
N1 & 1B & $2,16 \mathrm{~b}$ & Sedang & $2,69 \mathrm{~b}$ & Sedang & $2,41 \mathrm{ab}$ & Sedang \\
N2 & $1 \mathrm{~K}$ & $2,50 \mathrm{bc}$ & Sedang & $3,14 \mathrm{bc}$ & Tinggi & $2,08 \mathrm{ab}$ & Sedang \\
N3 & 1B+1K & $2,59 \mathrm{c}$ & Sedang & $3,24 \mathrm{c}$ & Tinggi & $2,32 \mathrm{bc}$ & Sedang \\
N4 & 2B+1K & $2,64 \mathrm{c}$ & Sedang & $3,30 \mathrm{c}$ & Tinggi & $2,76 \mathrm{c}$ & Sedang \\
N5 & 1B+2K & $2,42 \mathrm{bc}$ & Sedang & $2,84 \mathrm{bc}$ & Sedang & $2,16 \mathrm{bc}$ & Sedang \\
\hline
\end{tabular}

Keterangan: Angka yang diikuti dengan huruf yang sama menunjukkan hasil tidak berbeda nyata berdasarkan uji DMRT taraf 5\%; 1B $=4 \mathrm{t}$ biochar ha ${ }^{-1}$ dan $1 \mathrm{~K}=30 \mathrm{t} \mathrm{kompos} \mathrm{ha}^{-1} ; *=$ kriteria menurut Balai Penelitian Tanah (2009).

\section{N-total}

Unsur $\mathrm{N}$ merupakan unsur yang dibutuhkan oleh tanaman, berperan dalam pertumbuhan organ vegetatif tanaman, pembentukan klorofil, katalisator reaksi kimia, dan mempengaruhi penyerapan unsur hara lain. Jumlah $\mathrm{N}$ di dalam tanah sedikit, sementara kebutuhan dan kehilangan $\mathrm{N}$ di dalam tanah cukup besar. Pengaruh aplikasi kombinasi biochar sekam padi dengan kompos terhadap $\mathrm{N}$ total tanah disajikan pada Tabel 3. Hasil analisis ragam menunjukkan adanya pengaruh nyata dari aplikasi kombinasi biochar sekam padi dan kompos terhadap $\mathrm{N}$ total tanah inkubasi dan ditanami jagung. $\mathrm{N}$ total tanah yang memiliki kriteria rendah serta berbeda nyata dengan nilai $\mathrm{N}$ perlakuan kontrol. $\mathrm{N}$ total tertinggi pada 4 dan 7 MSI didapatkan pada perlakuan N5 (1B + $2 \mathrm{~K})$ dengan. Di lain pihak, pada tanah yang ditanami jagung, nilai $\mathrm{N}$ tertinggi didapatkan pada perlakuan N2 (1K). Kadar $\mathrm{N}$ total dipengaruhi oleh aplikasi kompos, hal ini sejalan dengan, Agustin et al. (2019) bahwa kompos mengandung karbon yang berperan sebagai penyedia energi bagi mikroorganisme tanah untuk merombak hara agar dapat tersedia bagi tanaman. Aplikasi biochar juga dapat meningkatkan kandungan $\mathrm{N}$ di dalam tanah. 
Jurnal Tanah dan Sumberdaya Lahan Vol 8 No 2: 451-460, 2021

e-ISSN:2549-9793, doi: 10.21776/ub.jts1.2021.008.2.16

Tabel 3. Pengaruh aplikasi biochar dan kompos terhadap $\mathrm{N}$ total tanah.

\begin{tabular}{cccccccc}
\hline Kode & Perlakuan & \multicolumn{6}{c}{ N total (\%) } \\
\cline { 3 - 8 } & & \multicolumn{5}{c}{ Tanah Inkubasi } & \multicolumn{3}{c}{ Tanah ditanami Jagung } \\
\cline { 3 - 7 } & & 4 MSI & $*$ & 7 MSI & $*$ & 7 MST & $*$ \\
\hline N0 & Kontrol & $0,16 \mathrm{a}$ & Rendah & $0,18 \mathrm{a}$ & Rendah & $0,15 \mathrm{a}$ & Rendah \\
N1 & 1B & $0,20 \mathrm{bc}$ & Rendah & $0,22 \mathrm{~b}$ & Sedang & $0,20 \mathrm{~b}$ & Rendah \\
N2 & 1K & 0,21 c & Sedang & $0,23 \mathrm{~b}$ & Sedang & $0,22 \mathrm{~b}$ & Sedang \\
N3 & 1B+1K & 0,20 bc & Rendah & $0,22 \mathrm{~b}$ & Sedang & $0,21 \mathrm{~b}$ & Sedang \\
N4 & 2B+1K & $0,19 \mathrm{~b}$ & Rendah & $0,21 \mathrm{ab}$ & Sedang & $0,21 \mathrm{~b}$ & Sedang \\
N5 & 1B+2K & 0,22 c & Sedang & $0,24 \mathrm{~b}$ & Sedang & $0,21 \mathrm{~b}$ & Sedang \\
\hline
\end{tabular}

Keterangan: Angka yang diikuti dengan huruf yang sama menunjukkan hasil tidak berbeda nyata berdasarkan uji DMRT taraf 5\%; 1B $=4 \mathrm{t}$ biochar ha ${ }^{-1}$ dan $1 \mathrm{~K}=30 \mathrm{t}$ kompos ha ${ }^{-1}$; MSI $=$ minggu setelah inkubasi; * = kriteria menurut Balai Penelitian Tanah (2009).

Selain itu, menurut Verdiana et al. (2011) aplikasi biochar dapat mempengaruhi aktivitas dari mikroorganisme di dalam tanah yang berperan dalam mineralisasi N. Di lain pihak menurut Putri et al. (2017) biochar mampu menjerap $\mathrm{NH}_{4}{ }^{+}$dan $\mathrm{NO}^{3-}$ sehingga mengurangi kehilangan $\mathrm{N}$ dari dalam tanah.

Rasio $C / N$

Hasil analisis ragam menunjukkan bahwa perlakuan aplikasi kombinasi biochar sekam padi dan kompos tidak berpengaruh nyata terhadap rasio $\mathrm{C} / \mathrm{N}$ tanah inkubasi $4 \mathrm{MSI}$ dan 7 MST pada tanah yang ditanami jagung, tetapi berpengaruh nyata terhadap rasio C/N 7 MSI. Pada tanah inkubasi $7 \mathrm{MSI}$ perlakuan N4 menghasilkan nilai rasio $\mathrm{C} / \mathrm{N}$ tertinggi yaitu sebesar 16 dan perlakuan kontrol menghasilkan nilai rasio $\mathrm{C} / \mathrm{N}$ terendah sebesar 10 . Perlakuan $\mathrm{N} 4(2 \mathrm{~B}+1 \mathrm{~K})$ pada tanah inkubasi 7 MSI tidak berbeda nyata dengan perlakuan N1, N3, dan $\mathrm{N} 5(1 \mathrm{~B}, 1 \mathrm{~B}+1 \mathrm{~K}$, dan $1 \mathrm{~B}+2 \mathrm{~K})$, namun berbeda nyata dengan perlakuan N2 (1K). Pengaruh aplikasi kombinasi biochar sekam padi dan kompos disajikan pada Tabel 4. Nilai $\mathrm{C} / \mathrm{N}$ sangat dipengaruhi oleh nilai $\mathrm{C}$ dan $\mathrm{N}$ dalam tanah inkubasi dan tanah yang ditanami jagung. Menurut Roesmarkam dan Yuwono (2002) jumlah mineralisasi $\mathrm{N}$ dan kandungan $\mathrm{N}$ total di dalam tanah yang berasal dari dekomposisi bahan organik akan meningkat seiring dengan meningkatnya $C$ organik di dalam tanah. Menurut Rusdiana dan Lubis (2012) jika kandungan $\mathrm{C}$ di dalam tanah lebih tinggi dibandingkan dengan kandungan $\mathrm{N}$ total di dalam tanah maka nilai rasio $\mathrm{C} / \mathrm{N}$ tanah akan semakin tinggi, sedangkan jika kandungan $\mathrm{C}$ dan $\mathrm{N}$ di dalam tanah relatif tinggi maka nilai Rasio $\mathrm{C} / \mathrm{N}$ tanah akan rendah.

Tabel 4. Pengaruh aplikasi biochar dan kompos terhadap rasio $\mathrm{C} / \mathrm{N}$ tanah.

\begin{tabular}{cccccccc}
\hline \multirow{2}{*}{ Kode } & Perlakuan & \multicolumn{5}{c}{ C/N tanah } \\
\cline { 3 - 7 } & & \multicolumn{5}{c}{ Tanah inkubasi } & \multicolumn{3}{c}{ Tanah ditanami Jagung } \\
\cline { 3 - 7 } & & 4 MSI(t) & $*$ & 7 MSI & $*$ & 7 MST(tn) & $*$ \\
\hline N0 & Kontrol & 11 & Sedang & $10 \mathrm{a}$ & Rendah & 11 & Sedang \\
N1 & $1 \mathrm{~B}$ & 11 & Sedang & $14 \mathrm{bc}$ & Sedang & 12 & Sedang \\
N2 & $1 \mathrm{~K}$ & 12 & Sedang & $12 \mathrm{ab}$ & Sedang & 10 & Rendah \\
N3 & $1 \mathrm{~B}+1 \mathrm{~K}$ & 13 & Sedang & $15 \mathrm{bc}$ & Sedang & 11 & Sedang \\
N4 & $2 \mathrm{~B}+1 \mathrm{~K}$ & 14 & Sedang & $16 \mathrm{c}$ & Tinggi & 13 & Sedang \\
N5 & $1 \mathrm{~B}+2 \mathrm{~K}$ & 11 & Sedang & $12 \mathrm{bc}$ & Sedang & 10 & Rendah \\
\hline
\end{tabular}

Keterangan: Angka yang diikuti dengan huruf yang sama menunjukkan hasil tidak berbeda nyata berdasarkan uji DMRT taraf $5 \%$; tn = tidak berbeda nyata menurut uji DMRT taraf $5 \%$; $1 \mathrm{~B}=4 \mathrm{t}$ biochar ha ${ }^{-1}$ dan $1 \mathrm{~K}=30$ t kompos ha ${ }^{-1} ; *=$ kriteria menurut Balai Penelitian Tanah (2009). 


\section{Jurnal Tanah dan Sumberdaya Lahan Vol 8 No 2: 451-460, 2021 e-ISSN:2549-9793, doi: 10.21776/ub.jts1.2021.008.2.16}

\section{Pengaruh biochar dan kompos terhadap serapan $\mathbf{N}$ tanaman jagung}

Penggunaan biochar dan kompos bertujuan untuk menyediakan unsur hara yang diperlukan bagi tanaman jagung. Unsur $\mathrm{N}$ penting bagi pertumbuhan tanaman terutama pada fase vegetatif maksimum. Pengaruh dari dosis biochar dan kompos terhadap serapan tanaman jagung disajikan pada Tabel 5. Hasil analisis ragam menunjukkan bahwa aplikasi biochar dan kompos berpengaruh nyata terhadap parameter berat kering tanaman jagung. Perlakuan N5 (1B $+2 \mathrm{~K})$ menghasilkan nilai berat kering tertinggi yaitu sebesar 93,73 $\mathrm{g} \mathrm{tan}^{-1}$ dan N0 (kontrol) menghasilkan nilai berat kering terendah yaitu sebesar $63,80 \mathrm{~g} \tan ^{-1}$.

Tabel 5. Pengaruh biochar dan kompos terhadap serapan $\mathrm{N}$ tanaman jagung.

\begin{tabular}{ccccc}
\hline Kode & Perlakuan & $\begin{array}{c}\text { Berat kering } \\
\left(\mathbf{g} \text { tan }^{-1}\right)\end{array}$ & $\begin{array}{c}\mathbf{N} \text { total tanaman } \\
\mathbf{( \% )}\end{array}$ & $\begin{array}{c}\text { Serapan } \mathbf{~} \\
\left(\mathbf{g} \text { tan }^{-1}\right)\end{array}$ \\
\hline N0 & Kontrol & $63,80 \mathrm{a}$ & $0,0033 \mathrm{a}$ & $0,21 \mathrm{a}$ \\
N1 & 1B & $65,95 \mathrm{ab}$ & $0,0058 \mathrm{~b}$ & $0,38 \mathrm{~b}$ \\
N2 & 1K & $68,05 \mathrm{ab}$ & $0,0062 \mathrm{~b}$ & $0,42 \mathrm{~b}$ \\
N3 & $1 \mathrm{~B}+1 \mathrm{~K}$ & $71,78 \mathrm{ab}$ & $0,0060 \mathrm{~b}$ & $0,44 \mathrm{~b}$ \\
N4 & 2B $1 \mathrm{~K}$ & $81,00 \mathrm{bc}$ & $0,0059 \mathrm{~b}$ & $0,48 \mathrm{bc}$ \\
N5 & 1B+2K & $93,73 \mathrm{c}$ & $0,0065 \mathrm{~b}$ & $0,61 \mathrm{c}$ \\
\hline
\end{tabular}

Keterangan: Angka yang diikuti dengan huruf yang sama menunjukkan hasil tidak berbeda nyata berdasarkan uji DMRT taraf $5 \% ; 1 \mathrm{~B}=4 \mathrm{t}$ biochar ha $\mathrm{a}^{-1}$ dan $1 \mathrm{~K}=30 \mathrm{t}$ kompos ha- ${ }^{-1}$.

Aplikasi kompos dan biochar dapat meningkatkan berat kering tanaman, hal ini sejalan dengan penelitian Widodo dan Kusuma (2018) bahwa berat kering tanaman jagung semakin meningkat seiring dengan meningkatnya pemberian dosis pupuk kompos. Ditambahkan dari Satria et al. (2015) interaksi pupuk kompos dengan NPK mampu meningkatkan berat kering tanaman. Hasil analisis ragam menunjukkan pengaruh nyata terhadap parameter $\mathrm{N}$ total tanaman. Perlakuan $\mathrm{N} 5(1 \mathrm{~B}+2 \mathrm{~K})$ menghasilkan persen $\mathrm{N}$ tanaman tertinggi, yaitu sebesar $0,0065 \%$ sedangkan $\mathrm{N} 0$ (kontrol) menghasilkan persen $\mathrm{N}$ total tanaman terendah, yaitu sebesar 0,0033\%. Menurut Wijanarko et al. (2012) saat proses dekomposisi berlangsung, mikroorganisme tanah memanfaatkan senyawa karbon yang berasal dari bahan organik sebagai sumber energi. Proses mineralisasi merupakan proses lanjutan dari proses dekomposisi yang penting bagi ketersediaan $\mathrm{N}$ di dalam tanah. Semakin meningkatnya proses mineralisasi $\mathrm{N}$, maka ketersediaan $\mathrm{N}$ di dalam tanah juga akan meningkat.

Hasil analisis ragam aplikasi biochar dan kompos menunjukan pengaruh nyata terhadap parameter serapan $\mathrm{N}$ tanaman jagung. Perlakuan N5 $(1 \mathrm{~B}+2 \mathrm{~K})$ menghasilkan nilai serapan $\mathrm{N}$ tertinggi yaitu sebesar $0,61 \mathrm{~g} \tan ^{-1}$ dan terendah sebesar 0,21 $\mathrm{g} \mathrm{tan}^{-1}$ ditemukan pada perlakuan N0 (kontrol). Hal ini sejalan dengan penelitian yang dilakukan oleh Yuliana et al. (2015) bahwa aplikasi pupuk kompos pada tanaman jagung dapat meningkatkan serapan $\mathrm{N}$ pada tanaman jagung dan mendapatkan hasil yang maksimal. Menurut Herman dan Resigia (2018), biochar mampu mengefektifkan aplikasi pupuk, yaitu dengan mengikat hara pada saat terjadinya kelebihan hara dan melepaskan hara jika tanaman kekurangan hara, sehingga tanaman yang diberi biochar tidak mengalami keracunan atau defisit hara.

\section{Pengaruh biochar dan kompos terhadap pertumbuhan tanaman jagung}

Tinggi tanaman dan jumlab daun

Tinggi tanaman dan jumlah daun merupakan salah satu parameter yang diukur untuk mengetahui pertumbuhan vegetatif tanaman. Tinggi dan jumlah daun tanaman jagung diukur untuk mengetahui pengaruh dari berbagai dosis rekomendasi kombinasi biochar sekam padi dan kompos. Pengaruh aplikasi kombinasi biochar sekam padi dan kompos terhadap tinggi tanaman dan jumlah daun jagung pada 1, 3 dan 5 MST disajikan pada Tabel 6. 
Jurnal Tanah dan Sumberdaya Lahan Vol 8 No 2: 451-460, 2021

e-ISSN:2549-9793, doi: 10.21776/ub.jts1.2021.008.2.16

Tabel 6. Pengaruh biochar dan kompos terhadap tinggi dan jumlah daun tanaman jagung.

\begin{tabular}{ccccccc}
\hline \multirow{2}{*}{ kode } & \multicolumn{2}{c}{ 1 MST } & \multicolumn{2}{c}{ 3 MST } & \multicolumn{2}{c}{ 5 MST } \\
\cline { 2 - 7 } & Tinggi & Daun & Tinggi & Daun & Tinggi & Daun \\
\hline N0 & 21,15 & 4 & $85,75 \mathrm{a}$ & 8 & $130,25 \mathrm{a}$ & 11 \\
N1 & 21,80 & 3 & $89,05 \mathrm{ab}$ & 9 & $136,13 \mathrm{ab}$ & 11 \\
N2 & 21,83 & 4 & $91,13 \mathrm{bc}$ & 9 & $142,50 \mathrm{bc}$ & 12 \\
N3 & 22,40 & 4 & $92,13 \mathrm{bc}$ & 9 & $143,00 \mathrm{bc}$ & 12 \\
N4 & 21,68 & 4 & $93,00 \mathrm{bc}$ & 11 & $144,38 \mathrm{bc}$ & 12 \\
N5 & 21,30 & 4 & $94,50 \mathrm{c}$ & 10 & $147,75 \mathrm{c}$ & 12 \\
\hline
\end{tabular}

Keterangan: Angka yang diikuti dengan huruf yang sama menunjukkan hasil tidak berbeda nyata berdasarkan uji DMRT taraf 5\%; tn = tidak berbeda nyata menurut uji DMRT taraf 5\%; 1B $=4$ t biochar ha ${ }^{-1}$ dan $1 \mathrm{~K}=30$ t kompos ha-1.

Hasil analisis ragam menunjukkan bahwa perlakuan aplikasi kombinasi biochar sekam padi dan kompos berpengaruh nyata terhadap tinggi tanaman jagung umur 3 dan 5 MST. Perlakuan N5 $(1 \mathrm{~B}+2 \mathrm{~K})$ menghasilkan tinggi tanaman tertinggi secara berturut-turut sebesar $94,50 \mathrm{~cm}$ dan $147,75 \mathrm{~cm}$, sedangkan kontrol menghasilkan tinggi tanaman terendah secara berturut-turut sebesar $85,75 \mathrm{~cm}$ dan $130,25 \mathrm{~cm}$ pada 3 dan 5 MST. Hal ini membuktikan bahwa unsur hara $\mathrm{N}$ dari perlakuan N5 $(1 \mathrm{~B}+2 \mathrm{~K})$ memberikan peningkatan terhadap tinggi tanaman jagung dibandingkan dengan perlakuan kontrol. Akan tetapi perlakuan N2, N3, N4, dan $\mathrm{N} 5(1 \mathrm{~K}, 1 \mathrm{~B}+1 \mathrm{~K}, 2 \mathrm{~B}+1 \mathrm{~K}$, dan $1 \mathrm{~B}+2 \mathrm{~K})$ tidak berbeda nyata, sedangkan perlakuan N1 (1K) tidak berbeda nyata dengan perlakuan kontrol. Aplikasi biochar sekam padi dapat meningkatkan tinggi dari tanaman jagung. Hal ini sejalan dengan pernyataan Gandahi et al. (2015) bahwa biochar mendorong mekanisme yang berperan dalam peningkatan pertumbuhan tanaman dan hara. Aplikasi biochar dapat meningkatkan kandungan $\mathrm{N}$ di dalam tanah, salah satu manfaat unsur $\mathrm{N}$ bagi tanaman adalah untuk merangsang pertumbuhan vegetatif tanaman, seperti batang, daun dan akar. Menurut Beah et al. (2015), pupuk kompos dapat meningkatkan serapan $\mathrm{N}$, penyerapan $\mathrm{N}$ meningkat dengan meningkatnya aplikasi pupuk organik. Penyerapan N diindikasikan dan adanya peningkatan pertumbuhan tanaman. Hasil analisis ragam menunjukkan bahwa perlakuan aplikasi kombinasi biochar sekam padi dan kompos tidak berpengaruh nyata terhadap jumlah daun tanaman jagung pada 1, 3, dan 5 MST. Hal ini karena tidak adanya persaingan antar atanaman terhadap cahaya matahari. Hal ini sejalan oleh pernyataan Anggun et al. (2017) bahwa tanaman tidak bersaing dalam pemanfaatan cahaya matahari sehingga cahaya yang dibutuhkan oleh tanaman masih tersedia dan menghasilkan jumlah daun yang sama. Aplikasi kombinasi biochar sekam padi dan kompos menghasilkan peningkatan jumlah daun setiap minggunya. Hal ini disebabkan oleh unsur $\mathrm{N}$ yang berperan dalam pertumbuhan tanaman jagung yang terdapat pada kompos dan biochar. Menurut Kastalani $e t$ al. (2017), $\mathrm{N}$ akan berasosiasi dengan pembentukan klorofil pada daun, sehingga akan meningkatkan proses fotosintesis dan memacu pertumbuhan jumlah daun pada tanaman.

\section{Hubungan antara sifat kimia tanah, pertumbuhan dan serapan nitrogen tanaman jagung}

Uji korelasi bertujuan untuk mengetahui derajat hubungan linear suatu parameter dengan parameter lainnya. Menurut Sekaran dan Bougie (2010), uji korelasi merupakan metode untuk menyatakan kuat hubungan satu parameter dengan parameter lainnya.. Hubungan antara sifat kimia tanah, pertumbuhan dan serapan $\mathrm{N}$ tanaman jagung disajikan pada Tabel 7.

\section{Hubungan Corganik dengan $\mathbf{N}$ total tanah}

Hasil uji korelasi antara C organik terhadap N total menunjukkan hubungan positif dan nyata. Hal ini menunjukkan bahwa semakin meningkatkan kadar $\mathrm{C}$ di dalam tanah maka kadar $\mathrm{N}$ total tanah juga akan meningkat. Kadar $\mathrm{C}$ organik di dalam tanah berpengaruh $\mathrm{N}$ total tanah sebesar $50 \%$. Kadar C organik tanah berpengaruh terhadap kadar $\mathrm{N}$ total tanah. 
Tabel 7. Hubungan antara sifat kimia tanah dan serapan $\mathrm{N}$ tanaman jagung.

\begin{tabular}{lccl}
\hline Hubungan Antar Parameter & $\mathbf{r}$ & $\mathbf{R}^{2}$ & Persamaan \\
\hline C organik (x), N total tanah (y) & $0,69^{*}$ & 0,50 & $\mathrm{Y}=0,0257 \mathrm{x}+0,1437$ \\
C organik (x), C/N (y) & $0,78^{*}$ & 0,60 & $\mathrm{Y}=3,1431 \mathrm{x}+4.2454$ \\
C organik (x), berat kering tanaman (y) & 0,39 & 0,15 & $\mathrm{Y}=7,9758 \mathrm{x}+51,414$ \\
C organik (x), N total tanaman (y) & $0,87^{*}$ & 0,76 & $\mathrm{Y}=0,0018 \mathrm{x}+0,0004$ \\
C organik (x), serapan N tanaman (y) & $0,71^{*}$ & 0,50 & $\mathrm{Y}=0,1678 \mathrm{x}-0,053$ \\
N total tanah (x), C/N (y) & 0,28 & 0,75 & $\mathrm{Y}=29,688 \mathrm{x}+6,7344$ \\
N total tanah (x), berat kering tanaman (y) & $0,57^{*}$ & 0,32 & $\mathrm{Y}=316 \mathrm{x}+5,585$ \\
N total tanah (x), N total tanaman (y) & $0,94^{*}$ & 0,89 & $\mathrm{Y}=0,0531 \mathrm{x}-0,0059$ \\
N total tanah (x), serapan N tanaman (y) & $0,86^{*}$ & 0,74 & $\mathrm{Y}=5.4688 \mathrm{x}-0,7616$ \\
C/N (x), N total tanaman (y) & $0,56^{*}$ & 0,31 & $\mathrm{Y}=0,0003 \mathrm{x}+0,0018$ \\
C/N (x), serapan N tanaman (y) & $0,42^{*}$ & 0,17 & $\mathrm{Y}=0,0248 \mathrm{x}+0,09964$ \\
Berat kering tanaman (x), N total tanaman (y) & $0,56^{*}$ & 0,31 & $\mathrm{Y}=6 \mathrm{E}-05 \mathrm{x}+0,0014$ \\
\hline
\end{tabular}

Keterangan: * Hubungan positif dan berbeda nyata menurut uji $\mathrm{r}$ taraf $5 \%$; $\mathrm{r}$ tabel $5 \% 0,4044$.

Hal ini karena $\mathrm{C}$ organik merupakan substrat bagi mikroorganisme tanah untuk memineralisasi N. Hal ini sejalan dengan pernyataan Benbi dan Ritcher (2002) bahwa proses mineralisasi $\mathrm{N}$ merupakan proses untuk menyediakan unsur $\mathrm{N}$ di dalam tanah. Proses mineralisasi mencakup proses dekomposisi bahan organik yang dibantu oleh mikroorganisme di dalam tanah dengan memanfaatkan senyawa $\mathrm{C}$ sebagai sumber energi. Ditambahkan oleh Roesmarkam dan Yuwono (2002) jumlah mineralisasi $\mathrm{N}$ akan meningkat apabila kadar $\mathrm{C}$ organik di dalam tanah juga meningkat.

\section{Hubungan $C$ organik dengan $N$ total tanaman dan serapan $N$ tanaman}

Hasil uji korelasi $\mathrm{C}$ organik terhadap $\mathrm{N}$ total tanaman dan serapan $\mathrm{N}$ tanaman menunjukkan hubungan positif dan nyata. Hal ini menunjukkan bahwa kenaikan kadar $\mathrm{C}$ organik di dalam tanah akan meningkatkan kadar $\mathrm{N}$ total tanaman dan serapan $\mathrm{N}$ tanaman. Hal uji regresi memperlihatkan bahwa kadar $\mathrm{C}$ organik di dalam tanah berpengaruh terhadap $\mathrm{N}$ tanaman sebesar $76 \%$ dan terhadap serapan $\mathrm{N}$ tanaman jagung sebesar $50 \%$. Unsur C organik di dalam tanah mempengaruhi nilai $\mathrm{N}$ total dan serapan $\mathrm{N}$ tanaman jagung, hal ini karena $\mathrm{C}$ organik mampu menyediakan hara yang dibutuhkan tanaman, khususnya N. Hal ini sejalan dengan pernyataan dari Chan et al. (2007) yaitu, dekomposisi dari $\mathrm{C}$ organik organik tanah dapat melepaskan hara seperti $\mathrm{N}$ dan $\mathrm{P}$, serta hara lain yang dibutuhkan tanaman untuk tumbuh.
Adanya karbon sebagai substrat bagi mikroorganisme tanah dapat membantu proses mineralisasi N. Menurut Wijanarko et al. (2012) proses mineralisasi merupakan proses yang penting bagi ketersediaan $\mathrm{N}$ di dalam tanah. Proses mineralisasi mencakup dekomposisi bahan organik untuk menghidrolisis protein kompleks. Saat proses dekomposisi berlangsung, mikroorganisme tanah memanfaatkan senyawa C organik sebagai sumber energi. Semakin meningkatnya proses mineralisasi $\mathrm{N}$, maka ketersediaan $\mathrm{N}$ di dalam tanah juga akan meningkat. Peningkatan ketersediaan $\mathrm{N}$ di dalam tanah akan meningkatkan serapan $\mathrm{N}$ oleh tanaman.

\section{Hubungan $\mathbf{N}$ total tanah dengan $\mathbf{N}$ total tanaman dan serapan $N$ tanaman}

Hasil uji korelasi $\mathrm{N}$ total tanah terhadap $\mathrm{N}$ total tanaman dan serapan $\mathrm{N}$ oleh tanaman menghasilkan hubungan nyata dan positif. Semakin tinggi persen $\mathrm{N}$ di dalam tanah maka kadar $\mathrm{N}$ total tanaman dan serapan $\mathrm{N}$ tanaman juga akan meningkat. Kadar $\mathrm{N}$ di dalam tanah berpengaruh terhadap $\mathrm{N}$ total tanaman sebesar $89 \%$ dan terhadap serapan $\mathrm{N}$ tanaman jagung sebesar $74 \%$. Kadar N- total di dalam tanah mempengaruhi $\mathrm{N}$ total tanaman dan serapan $\mathrm{N}$ tanaman jagung. Kadar $\mathrm{N}$ total tanah juga mempengaruhi serapan $\mathrm{N}$ oleh tanaman, semakin tinggi persen $\mathrm{N}$ total tanah maka $\mathrm{N}$ total tanaman dan serapan $\mathrm{N}$ tanaman juga akan semakin tinggi. Hal ini sejalan dengan pernyataan Supramudho et al. (2012) yaitu, 


\section{Jurnal Tanah dan Sumberdaya Lahan Vol 8 No 2: 451-460, 2021 e-ISSN:2549-9793, doi: 10.21776/ub.jts1.2021.008.2.16}

semakin tinggi kandungan $\mathrm{N}$ total tanah maka serapan $\mathrm{N}$ oleh tanaman juga semakin tinggi. Semakin tinggi aplikasi bahan organik ke dalam tanah maka serapan $\mathrm{N}$ oleh tanaman akan meningkat.

\section{Kesimpulan}

Aplikasi kombinasi biochar sekam padi dan kompos berpengaruh dalam meningkatkan $\mathrm{C}$ organik dan $\mathrm{N}$ total tanah, tetapi tidak berpengaruh terhadap $\mathrm{C} / \mathrm{N}$ tanah inkubasi. $\mathrm{C}$ organik dan $\mathrm{N}$ total tanah tertinggi diperoleh dari perlakuan biochar sekam padi : kompos secara berturut-turut $8 \mathrm{t} \mathrm{ha}^{-1}: 30 \mathrm{t} \mathrm{ha}^{-1}$ dan $4 \mathrm{t}$ $\mathrm{ha}^{-1}: 60 \mathrm{t} \mathrm{ha}^{-1}$. Aplikasi kombinasi biochar sekam padi : kompos $\left(8 \mathrm{t} \mathrm{ha}^{-1}: 30 \mathrm{t} \mathrm{ha}^{-1}\right)$ berpengaruh meningkatkan tinggi tanaman, berat kering, dan serapan $\mathrm{N}$ tanaman jagung, dengan peningkatan secara berturut turut yaitu 10, $84 \%, 29,96 \%$, dan $125,28 \%$ dibandingkan dengan perlakuan kontrol.

\section{Ucapan Terimakasih}

Rasa terima kasih diucapkan kepada Badan Tenaga Nuklir Nasional- Pusat Aplikasi Isotop dan Radiasi yang telah memberi fasilitas dan kesempatan bagi penulis untuk melakukan penelitian ini.

\section{Daftar Pustaka}

Agustin, E., Lukiwati, D.R. dan Wahyuni, S. 2019. Pengaruh inokulasi Bacillus aryabhattai terhadap pertumbuhan serta produksi tanaman padi pada media campuran kompos, biochar dan arang aktif. Prosiding Seminar Nasional Sains dan Enterpreneurship. ISBN : 9786029997538.

Andalusia, B., Zainabun. dan Arabia, T. 2016. Karakteristik tanah ordo Ultisol di Perkebunan Kelapa Sawit PT. Perkebunan Nusantara I (Persero) Cot Girek Kabupaten Aceh Utara. Jurnal Kawista 1(1): 45-49.

Anggun., Supriyono. dan Syamsiyah, J. 2017. Pengaruh jarak tanam dan pupuk N, P, K, terhadap pertumbuhan dan hasil garut. Agrotech Research Journal 1(2): 33-38.

Badan Ketahanan Pangan. 2018. Buletin Pasokan dan Harga Pangan. http://bkp. pertanian.go.id/storage/app/uploads/public/ 5b0/523/0a8/5b05230a887ad919144521.pdf diakses pada 13 Desember 2019.

Balai Penelitian Tanah. 2009. Analisis Kimia Tanah, Tanaman, Air, dan Pupuk. Balai Besar Litbang
Sumber Daya Lahan Pertanian Balai Pengembangan dan Penelitian Pertanian Departemen Pertanian.215 hal.

Beah, A.A., Norman, P.E., Scholberg, J.C., Lantinga, E.A. and Conteh, A.R. 2015. Effect of organic manure on $\mathrm{N}$ mineralization, $\mathrm{N}$ accumulation, $\mathrm{N}$ use effeciency and apparent $\mathrm{N}$ recovery of cauliflower. International Journal of Plant \& Soil Science 4(3): 265-272.

Benbi, D.K dan Ritcher, J. 2002. A critical review of some approaches to modelling nitrogen mineralization. Biology and Fertility of Soils 35: 168-183.

Chan, K.Y., Zwieten, L.V., Meszaros, I., Downie, A. and Joseph, S. 2008. Agronomic values of greenwaste biochar as a soil amendement. Australian Journal of Soil Research 45: 629-634.

De Luca, T.H., MacKenzie, D. and Gundale, M.J. 2009. Biochar Effects on Soil Nutrient Transformation. Oregon State University: 251-270.

Ermadani, M. dan Muzar, A. 2011. Pengaruh aplikasi limbah cair pabrik kelapa sawit terhadap hasil kedelai dan perubahan sifat kimia tanah Ultisol. Jurnal Agronomi Indonesia 39(3):160-167.

Firda., Mulyani, O. dan Yuniarti, A. 2016. Pembentukan, karakterisasi serta manfaat asam humat terhadap adsorbsi logam berat. Soilrens 14(2): 9-13

Firnia, D. 2009. Sifat kimia Ultisols Banten akibat pengolahan tanah dan pemberian pupuk kompos. Jurnal Agroekotek 1(1): 52-57.

Gandahi. A.W., Baloch, S.F., Sarki, M.S., Gandahi, R. and Lashari, M.S. 2015. Impact of rice husk biochar and macronutrient fertilizer on fodder maize and soil properties. International Journal of Bioscience 7(4): 12-21.

Gani, A. 2009. Potensi arang hayati biochar sebagai komponen teknologi perbaikan produktivitas lahan pertanian. Jurnal Iptek Tanaman Pangan 4(1): 33-48.

Herman, W. dan Resigia, E. 2018. Pemanfaatan biochar sekam padi dan kompos jerami padi terhadap pertumbuhan dan produksi padi pada tanah ordo Ultisol. Jurnal Ilmiah Pertanian 15(1): 42-50.

Kastalani, M., Kusuma, E. dan Melati, S. 2017. Pengaruh pemberian pupuk bokashi terhadap pertumbuhan vegetatif rumput gajah. Ziraa'ah 42(2): 123-127.

Mulyani, A., Rachman, A. dan Dairah, A. 2010. Penyebaran lahan masam, potensi dan ketersediaannya untuk pengembangan pertanian. Prosiding Simposium Nasional Pendayagunaan Tanah Masam. Pusat Penelitian dan Pengembangan Tanah dan Agroklimat. Bogor. Hal: 23-24. 


\section{Jurnal Tanah dan Sumberdaya Lahan Vol 8 No 2: 451-460, 2021 \\ e-ISSN:2549-9793, doi: 10.21776/ub.jts1.2021.008.2.16}

Pane, M.A., Damanik, M.M.B. dan Sitorus, B. 2014. Pemberian bahan organik kompos jerami padi dan abu sekam padi dalam memperbaiki sifat kimian tanah Ultisol serta pertumbuhan tanaman jagung. Jurnal Online Agroekoteknologi 2(4) : $1426-1432$.

Putri, V.I., Mukhlis. dan Hidayat, B. 2017. Pemberian beberapa jenis biochar untuk memperbaiki sifat kimia tanah Ultisol dan pertumbuhan tanaman jagung. Jurnal Agroekoteknologi FP USU 5(4): 824-828.

Roesmarkam, A. dan Yuwono, N.W. 2002. Ilmu Kesuburan Tanah. Kanisius: Jakarta.

Rusdiana, O. dan Lubis, R.Y. 2012. Pendugaan korelasi antara karakteristik tanah terhadap cadangan karbon pada hutan sekunder. Jurnal Silvikultur Tropika 3(1): 14-21.

Satria, N., Wardati. dan Khoiri, M.A. 2015. Pengaruh pemberian kompos tandan kosong kelapa sawit dan pupuk NPK terhadap pertumbuhan bibit tanaman gaharu. JOM Faperta 2(1): 1-14.

Sekaran, U. and Bougie, R. 2010. Research Methods for Business: A Skill Building Approach. John Wiley and sons, inc. : London

Siregar, P. dan Supriadi, F. 2017. Pengaruh pemberian beberapa sumber bahan organik dan masa inkubasi terhadap beberapa aspek kimia kesuburan tanah Ultisol. Jurnal Agroekoteknologi FP USU 5(2): 256-264.

Supramudho, G.N., Jauhari, S., Mujiyo. dan Sumani. 2012. Efisiensi serapan nitrogen dan hasil tanaman padi pada berbagai imbangan pupuk kandang puyuh dan pupuk anorganik di lahan Palur, Sukoharjo, Jawa Tengah. Bonorowo Wetlands 2(1): 11-18.
Syahputra, E., Fauzi. dan Razali. 2015. Karakteristik sifat kimia sub grup tanah Ultisol di beberapa wilayah Sumatera Utara. Jurnal Agroekoteknologi 4(1): 1796-1803.

Verdiana, M.A., Thamrin, H. dan Sumarni, T. 2016. Pengaruh dosis biochar sekam padi dan pupuk NPK terhadap pertumbuhan dan hasil tanaman jagung. Jurnal Produksi Tanaman 4(8): 611-616.

Wahyuningtyas, R.S. 2011. Mengelola tanah Ultisol untuk mendukung pertumbuhan tegakan. Galam 5(1): 85-89.

Widodo, K.H. dan Kusuma, Z. 2018. Pengaruh kompos terhadap sifat fisik tanah dan pertumbuhan tanaman jagung di Inceptisol. Jurnal Tanah dan Sumberdaya Lahan 5(2): 959967.

Wijanarko, A., Purwanto, B.H., Shiddieq, D.F. dan Indradewa, D. 2012. Pengaruh kualitas bahan organik dan kesuburan tanah terhadap mineralisasi nitrogen dan serapan $\mathrm{N}$ oleh tanaman ubikayu di tanah Ultisol. Jurnal Perkebunan \& Lahan Tropika 2(2): 1-14.

Yuliana, A., Sumarni, T. and Islami, T. 2015. Application of bokashi and sunn hemp to improve inorganic fertilizer efficiency on maize. Journal of Degraded and Mining Lands Management 3(1): 433-438. 